\title{
Pengaruh Penggunaan Media Puzzle Terhadap Hasil Belajar Matematika Siswa Kelas III SD di Kabupaten Gowa
}

\author{
Bahar $^{1}$, Risnawati ${ }^{2}$ \\ ${ }^{1,2}$ Program Studi Pendidikan Matematika FKIP UNSA Makassar \\ 1baharbethatwins@gmail.com \\ 2risnawatiunsa@gmail.com
}

\begin{abstract}
ABSTRAK
Penelitian ini menelaah Pengaruh Penggunaan Media Puzzle terhadap Hasil Belajar Siswa pada Mata Pelajaran Matematika Kelas III SD Inpres Taeng-Taeng Kabupaten Gowa. Masalah dalam penelitian ini adalah: (1) bagaimanakah penggunaan media puzzle terhadap hasil belajar siswa kelas III SD di Kabupaten Gowa?. (2) apakah ada pengaruh yang signifikan penggunaan media puzzle terhadap hasil belajar matematika siswa kelas III SD di Kabupaten Gowa? Tujuan penelitian ini adalah: (1) untuk mengetahui bagaimanakah penggunaan media puzzle terhadap hasil belajar siswa kelas III SD di Kabupaten Gowa. (2) untuk mengetahui pengaruh yang signifikan penggunaan media puzzle terhadap hasil belajar matematika siswa kelas III SD di Kabupaten Gowa. Pendekatan yang digunakan adalah pendekatan kuantitatif Jenis penelitian yang dilakukan adalah True-Experimental Design adalah sampel yang digunakan untuk eksperimen maupun kelompok kontrol diambil secara random dari populasi tertentu. Desain penelitian yang digunakan dalam penlitian ini adalah Desain Matching Pretest-Posttest Control Group Design. penelitian sampel acak (Therandomized pretest-posttest control grouf design. Populasi dalam penelitian ini adalah keseluruhan siswa kelas III SD di Kabupaten Gowa yang berjumlah 836 Sekolah Dasar. Adapun yang menjadi sampel adalah siswa kelas III SD Inpres Taeng-Taeng Kabupaten Gowa sebanyak 58 orang yaitu 28 sebagai kelas eksperimen dan 28 sebagai kelas konrol. Teknik pengumpulan data dalam penelitian ini observasi, tes hasil belajar dan dokumentasi. Teknik analisis data terdiri dari Uji Normalitas, Uji Homogenitas dan Uji Hipotesis. Hasil penelitian menunjukkan bahwa: Penggunaan media Puzzle pada mata pelajaran matematika di Taeng-Taeng Kabupaten Gowa memberikan pengaruh positif terhadap peningkatan hasil belajar siswa yang meningkat sehingga memberikan pengaruh yang signifikan.
\end{abstract}

Kata kunci: media puzzel, hasil belajar matematika

PENDAHULUAN

Belajar merupakan kebutuhan manusia, berbagai kemajuan yang telah diraih pada masa ini merupakan hasil proses belajar yang telah dilakukan manusia berabad-abad yang lalu. Manusia pada dasarnya mempunyai sifat selalu ingin tahu, hal itulah yang mendorong manusia untuk terus belajar, bahkan pada hakikatnya akan terus belajar sampai akhir hayat. Belajar pada dasarnya terbagi atas dua bagian, yaitu belajar secara mandiri (autodidak) dan belajar yang dilakukan secara formal di sekolah atau pendidikan yang diselenggarakan oleh instansi lembaga pendidikan.

Pendidikan merupakan syarat penting bagi perkembangan dan kemajuan suatu bangsa. Tanpa hal tersebut suatu negara tidak akan maju dan sejajar dengan bangsa-bangsa lainnya di dunia. UNESCO menetapkan empat pilar utama pendidikan untuk menghadapi abad ke -21, yaitu (1) Learning to know, yaitu belajar tidak hanya berorientasi kepada hasil belajar, tetapi harus beroirientasi kepada proses belajar, (2) Learning to do yaitu belajar untuk penguasaan kompetensi, (3) Learning to be yaitu membentuk manusia yang menjadi dirinya sendiri, dan (4) Learning to live together yaitu belajar untuk bekerja sama. Oleh karena itu perlu dilakukan pengembangan secara berkelanjutan dalam bidang pendidikan demi mewujudkan generasi penerus yang terdidik dan memiliki akhlak mulia. Keberhasilan dunia pendidikan pada abad-21, akan tergantung pada sejauh mana dikembangkannya keterampilan-keterampilan baru untuk mengikuti perkembangan ilmu pengetahuan dan teknologi.

Kemajuan suatu bangsa ditentukan dari bagaimana perkembangan pendidikan bagi anak bangsa itu. Kemajuan dalam satuan waktu jangka panjang akan dapat memprediksi 
kualitas bangsa pada sekian puluh tahun ke depan. Akhir dari hasil pendidikan yang terencana menghasilkan buah di mana masyarakat rata-rata berpendidikan tinggi. Masyarakat suatu negara yang maju akan melahirkan kemajuan dalam berbagai bidang seperti pembangunan, ilmu pengetahuan, teknologi, ekonomi, sosial, politik, dan peradaban. Hal ini menunjukkan keberadaan pendidikan demikian pentingnya. Untuk memperoleh pendidikan yang maju, tinggi, dan berkembang perlunya suatu perencanaan matang yang berhubungan dengan tujuan pendidikan nasional.

Kualitas manusia yang dihasilkan oleh pendidikan merupakan modal utama bagi tercapainya tujuan pembangunan nasional. Manusia yang dimaksud adalah manusia yang sempurna dalam arti terwujudnya pribadi yang serasi, selaras dan seimbang dalam moral, spritual, sosial, intelektual dan fisik. Dalam rangka mewujudkan tujuan pendidikan nasional dimaksud maka kegiatan-kegiatan dalam penyelenggaraan proses pembelajaran harus diikuti dengan tenaga pengajar di sekolah yang berkualitas, dalam arti berkompetensi dalam bidangnya sebagai tenaga edukatif sehingga menunjang penyelenggaraan pembelajaran untuk meningkatkan hasil belajar siswa seperti yang diharapkan tujuan pendidikan nasional yang hendak dicapai.

Guru sebagai salah satu komponen penentu sumber daya manusia yang berkualitas mempunyai peranan penting dalam mewujudkan keberhasilan siswa dalam belajar. Oleh karena itu, guru dituntut untuk mampu menguasai dan memanfaatkan ilmu pengetahuan dan teknologi demi efektifitas pelaksanaan pembelajaran. Sebagai pengelola proses pembelajaran guru hendaknya memilih dan mendesain berbagai komponen pendukung pembelajaran guna meminimalkan kendala yang mungkin terjadi di kelas.

Salah satu komponen penting yang harus diperhatikan guru demi terselenggaranya pembelajaran yang efektif dan efisien adalah pemilihan media yang akan digunakan dalam proses pembelajaran. Penggunaan media pembelajaran sebagai salah satu komponen pembelajaran sangat membantu guru dalam proses pembelajaran dan menentukan kualitas pembelajaran yang berdampak pada pencapaian tujuan pembelajaran yang dicapai oleh siswa setelah proses pembelajaran dilaksanakan. Azhar Arsyad (2014), menyatakan bahwa media adalah bagian yang tidak terpisahkan dari suatu proses kegiatan belajar mengajar demi tercapainya tujuan pendidikan pada umumnya dan tujuan pembelajaran di sekolah khususnya

Pentingnya penggunaan media dalam proses pembelajaran juga dipertegas oleh pendapat Edgar Dale, Finn dan Hobar (Ahmad,2007) yang menyatakan bahwa penggunaan media pembelajaran menjadi penting sebab akan memberikan pengalaman konkrit dan menghindarkan abstraksi, lebih menarik perhatian siswa, meningkatkan perbendaharaan kata serta memberikan pengalaman belajar yang lebih berarti bagi siswa.

Keberadaan media pembelajaran akan menciptakan suasana belajar yang lebih kondusif dikarenakan proses transformasi pesan pembelajaran dari sumber belajar kepada siswa berlangsung lebih menyenangkan dan efektif yang berdampak pada pemahaman siswa terkait dengan materi pelajaran.

Pembelajaran matematika adalah ilmu yang mempelajari tentang perhitungan yang membutuhkan pemikiran kritis dalam memahami setiap konsep pada materinya. Jika dilihat secara langsung matematika mudah dikerjakan mengingat semua orang bisa berhitung tetapi tidak semua orang bisa mengoprasikannya apalagi jika sudah menyangkut rumus-rumus.

Berdasarkan observasi awal yang dilakukan dengan persetujuan guru kelas III SD Inpres Taeng-Taeng Kabupaten Gowa, peneliti memperoleh informasi hasil belajar siswa dalam mata pelajaran Matematika masih tergolong rendah di bawah KKM (nilai KKM pada mata pelajaran matematika yakni 68), dari 28 orang siswa hanya 12 orang yang mencapai nilai KKM, berdasar dari hal tersebut maka peneliti melakukan tanya jawab secara langsug didepan kelas terkait tentang pelajaran matematika namun sebagian besar siswa mengatakan bahwa, matematika adalah pelajaran yang sulit dan membosankan, hal ini merupakan suatu masalah yang tidak boleh dibiarkan berlarut karena kelas III merupak Langkah awal untuk menuju ke kelas tinggi. Olenya itu penelitian ini perlu untuk dilakukan sebagai solusi dalam pembelajaran matematika dengan menggunakan media puzzle agar siswa 
lebih aktif, kritis, dan kreatif dalam memcahkan masalah yang ada.

Berdasarkan uraian tersebut, peneliti berupanya mengadakan penelitian dengan judul Pengaruh Penggunaan Media Puzzle Terhadap Hasil Belajar Matematika Siswa Kelas III SD Kabupaten Gowa.

\section{Media Puzzle}

Puzzle di Indonesia sering disebut dengan nama permainan bongkar pasang. Menurut Alfiatun N, dkk (2013), puzzle adalah permainan menyusun potongan-potongan gambar agar tercipta suatu gambar yang utuh.[3]

Puzzle adalah suatu alat permainan yang bisa membantu membangun koordinasi mata, tangan dan untuk belajar tentang konsep pemasangan dalam bentuk yang terdiri dari dua atau tiga permainan bongkar pasang. Sedangkan media puzzle adalah alat untuk permainan edukatif yang menyerupai benda model tiruan yang dapat merangsang kemampuan motorik halus siswa dan dimainkan dengan cara membongkar pasang kepingan puzzle berdasarkan pasangannya. Bahan puzzle cukup beragam, ada yang berasal dari kayu, kertas, plastik, karet, busa (foam), dan lain sebagainya.

Media puzzle termaksud media visual karena menggunakan indera penglihatan. Media puzzle merupakan salah satu media permainan yang dapat digunakan pada pembelajaran pada materi bangun ruang karena puzzle bersifat edukatif bermanfaat untuk meningkatkan keterampilan kognitif, motorik halus, sosial dan melatih kesabaran.

1. Bentuk-bentuk Puzzle

Menurut Siatan (2014) Puzzle dibagi menjadi beberapa bentuk, diantaranya:

a) Puzzle konstruksi merupakan kumpulan potongan-potongan yang terpisah, yang dapat digabungkan kembali menjadi beberapa model.

b) Puzzle batang merupakan permainan tekateki matematika sederhana namun memerlukan pemikiran kritis dan dimainkan dengan cara membuat bentuk sesuai yang kita inginkan ataupun menyusun gambar.

c) Puzzle lantai yaitu puzzle yang terbuat dari bahan sponge (karet/busa) sehingga baik untuk alas bermain anak-anak di atas lantai. d) Puzzle angka yaitu sejenis bongkar pasang yang bermanfaat untuk mengenalkan angka. Selain itu anak dapat melatih kemampuan berpikir logisnya dengan menyusun angka sesuai urutannya.

e) Puzzle transportasi yaitu merupakan bongkar pasang yang memiliki gambar berbagai macam kendaraan darat, laut dan udara.

f) Puzzle logika merupakan puzzle gambar yang dapat mengembangkan keterampilan serta anak berlatih untuk memecahkan masalah sehingga membentuk suatu gambar yang utuh.

g) Puzzle geometri merupakan puzzle yang dapat mengembangkan keterampilan anak untuk mengenali bentuk geometri (segitiga, lingkaran, persegi, persegi panjang dan lain-lain).

h) Puzzle penjumlahan dan pengurangan merupakan puzzle yang dapat mengembangkan kemampuan logika matematika anak. Dengan puzzle penjumlahan dan pengurangan anak memasangkan kepingan puzzle sesuai dengan gambar pasangannya.

Puzzle yang akan digunakan dalam pembelajaran matematika tersebut adalah puzzle jenis konstruksi dengan materi pokok pecahan sederhana. Media puzzle merupakan salah satu media permainan yang dapat digunakan pada mata pelajaran matematika khususnya materi pecahan sederhana karena puzzle konstruksi terdiri atas beberapa potongan puzzle yang akan disusun menjadih gambar utuh yakni gambar persegi. Potonganpotongan puzzle tersebut dijadikan acuan dalam pecahan sederhana tersebut.

\section{Manfaat Permainan Puzzle}

Tilong (2016) mengemukakan bahwa ada banyak manfaat yang dapat diperoleh dari permainan puzzle bagi anak, diantaranya:

a) meningkatkan kemampuan berpikir anak dan membuat anak akan melatih sel-sel otaknya untuk mengembangkan kemampuan berpikirnya dan berkonsetrasi guna menyelesaikan potongan-potongan kepingan gambar pada puzzle tersebut.

b) Lewat permainan puzzle, anak juga bisa melatih koordinasi tangan dan matanya untuk mencocokkan kepingan-kepingan puzzle serta menyusunnya menjadi satu gambar utuh. 
c) Meningkatkan fungsi kognitif anak. Dalam konteks ini, perlu diketahui bahwa keterampilan kognitif (cognitive skill) sangat berkaitan dengan kemampuan belajar dan memecahkan masalah. Dengan bermain puzzle, anak akan mencoba memecahkan masalah, yaitu menyusun gambar. Terlebih, puzzle mempunyai bentuk gambar yang lucu dengan warnawarni yang sangat menarik.

d) Sehingga, anak akan lebih tertarik karena pada dasarnya setiap anak menyukai gambar dan warna yang menarik. Ketika bermain puzzle, anak akan mengenal bentuk, ukuran, serta warna yang berbeda pada objek. Hal ini akan membantu anak belajar untuk meletakkan segala sesuatu secara bersamaan dan harmonis, yang secara otomatis membuat keterampilan kognitif anak terlatih.

e) Puzzle dalam bentuk gambar manusia akan melatih nalar anak. Anak akan menyimpulkan letak kepala, tangan, kaki, dan lain sebagainya sesuai logika. Misalnya, jika sudah menaruh bagian hidung, berarti mulut ada dibagian bawahnya.

f) Dengan bermain puzzle anak menjadi lebih peka terhadap hal-hal yang terjadi di lingkungannya. Anak menjadi lebih kreatif, kritis, dan kreatif. Di sini akan terbangun kecerdasan spatial visual dan intrapersonal.

Berdasarkan pendapat ahli dapat disimpulkan bahwa tujuan puzzle yakni meningkatkan kemampuan berpikir anak, melatih koornidasi mata dan tangan untuk mencocokkan kepingan-kepingan puzzle, meningkatkan keterampilan kognitif anak, melatih nalar anak, dan menjadikan anak peka terhadap lingkungannya.

\section{Kelebihan Permainan puzzle}

Ayu (2014) mengemukakan kelebihan permainan puzzle sebagai berikut:

a) Gambar bersifat konkret karena melalui gambar siswa dapat melihat dengan jelas sesuatu.

b) Gambar dapat mengatasi keterbatasan waktu, tidak semua objek, benda dapat dibawa ke dalam kelas.

c) Gambar dapat menarik perhatian dan minat siswa.

Tilong (2016) mengemukakan bahwa bermain puzzle, anak akan mengenal bentuk, ukuran, serta warna yang berbeda pada objek.
Hal ini akan membantu anak belajar untuk meletakkan segala sesuatu secara bersamaan dan harmonis, yang secara otomatis membuat keterampilan kognitif anak terlatih. Di samping itu, puzzle dalam bentuk gambar manusia akan melatih nalar anak.

\section{Kekurangan Permainan Puzzle}

Ayu (2014) mengemukakan kekurangan permainan Puzzle

a) Membutuhkan waktu lebih banyak

b) Menuntut kreativitas siswa

c) Kelas menjadi kurang terkendali

d) Media puzzle lebih menekankan pada indera penglihatan (visual)

e) Gambar yang terlalu kompleks kurang efektif untuk pembelajaran

f) Gambar kurang maksimal bila diterapkan dalam kelompok besar

Berdasarkan pendapat ahli dapat disimpulkan bahwa kekurangan permainan puzzle adalah membutuhkan waktu yang banyak untuk menghubungkan kepingankepingan puzzle, kelas menjadi ribut apabila siswa tidak menemukan pasangan dari puzzle tersebut, dan membutuhkan tingkat kefokusan yang tinggi.

\section{Tujuan Permainan Puzzle}

Prima (2016) mengemukakan tujuan permainan puzzle sebagai berikut:

a. Menumbuhkan rasa kebersamaan antar anak. Jika ada permainan dalam satu kelompok, maka kebersamaan dalam satu kelompok akan tumbuh

b. Melatih strategi dalam kelompok untuk merampungkan permainan puzzle, maka ada strategi yang harus digunakan. Dengan adanya kebersamaan dalam kelompok, strategi permainan ini akan mudah terpecahkan.

c. Melatih memecahkan masalah bersamasama. Jika permainan dilakukan dengan bekerja kelompok, maka akan mudah menyelesaikan permainan puzzle ini.

d. Menumbuhkan saling memiliki diantara anak. Setiap anak akan merasa memiliki jika bekerja sama kelompok.

e. Menumbuhkan sikap saling menghargai diantara sesama anak. Dalam permainan kelompok, pasti setiap anak memiliki gagasan untuk memecahkan masalah. Namun, ketika kerja kelompok, mereka harus bias menghargai pendapat orang lain. 
f. Menghibur para siswa di dalam kelas. Permainan menjadi salah satu media penghibur siswa disela-sela penerimaan materi.

\section{Ketentuan Permainan Puzzle}

Prima (2016) mengemukakan ketentuan permainan puzzle sebagai berikut:
a. Waktu permainan : 15-30 menit.
b. Sifat permainan : perorangan atau kelompok
c. Tempat bermain : dalam ruangan
d. Bahan-bahan : pulpen, kertas, dan puzzle

7. Mekanisme Permainan Puzzle Prima (2016) mengemukakan mekanisme permainan puzzle sebagai berikut:

a) Carilah gambar-gambar yang berkaitan dengan materi pembelajaran, misalnya pulau jawa, gambar sekolah, ataupun pemandangan seperti gunung.

b) Buatlah gambar dari puzzle tersebut.

c) Anda bisa membuat puzzle dengan menggunakan aplikasi yang ada di komputer.

d) Jika tidak bias membuat puzzle sendiri, anda bias membeli puzzle di toko yang tersedia.

e) Buatlah kelompok dan sesuaikan dengan jumlah puzzle yang ada.

f) Berilah tiap kelompok satu puzzle.

g) Puzzle yang sudah dibagikan, untuk dilepas terlebih dahulu potongan-potongannya.

h) Hitung 1-3 tanda permainan dimulai.

i) Berikan waktu secukupnya untuk menyelesaikan permainan ini.

j) Pemenang dalam permainan ini adalah kelompok yang berhasil membentuk gambar utuh, atau kelompok yang paling banyak menyusun potongan-potongan puzzle.

k) Koreksi puzzle yang sudah disusun oleh anak, akhiri permainan ini dengan gembira yaitu dengan tepuk tangan bersama atau dengan memberikan pujian kepada anakanak.

\section{Belajar}

Menurut Whitaker (Rusman,2015:13)

bahwa "belajar adalah proses dimana tingkah laku ditimbulkan atau diubah melalui latihan dan pengalaman". Menurt Gagne (Riyanto,2009) menyatakan bahwa "belajar merupakan kecenderungan perubahan pada diri manusia yang dapat dipertahankan selama proses pertumbuhan". Sedangkan pengertian belajar juga dikemukakan oleh Crow \& Crow (Rusman,2015) bahwa "belajar adalah diperolehnya kebiasaan-kebiasaan, pengetahuan dan sikap baru".

Berdasarkan pendapat ahli, dapat ditarik batasan bahwa belajar merupakan suatu proses yang terjadi dalam diri seseorang untuk memperoleh pengetahuan, keterampilan dan sikap sebagai akibat dari terjadinya proses latihan dan pengajaran sebelumnya dimana hal tersebut bersifat relatif permanen.

1. Hasil Belajar

Hamalik

(Rusman,

mengemukakan bahwa "hasil belajar itu dapat terlihat dari terjadinya perubahan dari persepsi dan perilaku, termasuk juga perbaikan perilaku".
Menurut
Rusman

mengemukakan "hasil belajar adalah sejumlah pengalaman yang diperoleh siswa yang mencakup ranah kognitif, afektif dan psikomotor". Sementara itu, Suprijono (2014) mengemukakan "hasil belajar adalah perubahan perilaku secara keseluruhan bukan hanya salah satu aspek potensi kemanusiaan saja". Berdasarkan beberapa pendapat, perlu diperhatikan beberapa hal tentang hasil belajar yakni :

a) Hasil belajar merupakan kemampuan yang dimiliki atau dicapai setelah siswa menempuh proses belajar

b) Hasil belajar merupakan prestasi belajar siswa

c) Hasil belajar dapat diketahui setelah guru melakukan penilaian pada siswa.

2. Faktor yang Memperngaruhi Hasil Belajar Suryabrata (2012) yang menggolongkan faktor yang mempengaruhi hasil belajar menjadi dua bagian, yaitu faktor intern dan faktor ekstern. Faktor intern adalah faktor yang ada dalam diri individu yang sedang belajar, sedangkan faktor ekstern adalah faktor yang ada diluar diri individu.

Secara lebih rinci Munadi (Rusman, 2015) merinci faktor yang mempengaruhi hasil belajar yakni : 1) Faktor internal meliputi Faktor Fisiologis, Faktor Psikologis, 2) Faktor eksternal meliputi Faktor Lingkungan, Faktor instrumental. 


\section{METODE PENELITIAN}

Pendekatan yang digunakan dalam penelitian ini adalah pendekatan. Jenis penelitian yang dilakukan adalah TrueExperimental Design adalah sampel yang digunakan untuk eksperimen maupun kelompok kontrol diambil secara random dari populasi tertentu. Penelitian ini di dilaksanakan di SD Inpres Taeng-Taeng yang Kecamatan Somba Opu Kabupaten Gowa yang juga sebagai sampel dalam penelitian ini dimana populasinya adalah keseluruhan siswa kelas III SD yang ada di Kabupaten Gowa.

Adapun model rancangan penelitian yang digunakan adalah Desain Matching Pretest-Posttest Control Group Design dengan teknik pengumpulan data yaitu Observasi, Tes Hasil Belajar dan dokumentasi. Pembelajaran dilaksanakan selama delapan kali pertemuan. Pertemuan pertama pretest yang dilaksanakan dikelas kontrol dan eksperimen. Pertemuan kedua, ketiga, keempat, kelima, keenam, dan tujuh adalah perlakuan (treatmen) pada kelas kontrol dan eksperimen masing-masing tiga kali pertemuan. Sementara pertemuan kedelapa posttest yang di laksanakan pada kelas ekperimen dan kelas kontrol. Setiap pertemuan dilakukan selama 2 x 35 menit. Waktu yang dipergunakan tersebut disesuaikan dengan jam pelajaran matematika di Kelas III SD Inpres Taeng-Taeng Kabupaten Gowa.

Kemudian teknik analisis data yaitu Analisis statistika inferensial digunakan untuk menguji hipotesis penelitian dengan menggunakan uji-t. Namun sebelum dilakukan pengujian hipotesis, terlebih dahulu dilakukan uji normalitas dan homogenitas. Pengujian normalitas yang digunakan adalah Kolmogorov-Smirnov untuk mengetahui apakah data yang mengikuti populasi berdistribusi normal. Kriteria yang digunakan adalah data hasil belajar dikatakan mengikuti populasi yang berdistribusi normal jika nilai p-value $>\alpha=0,05$. Sementara untuk pengujian homogenitasnya digunakan Test of Homogeneity of variance yang bertujuan untuk mengetahui apakah variansi kedua data homogen. Data hasil belajar yang diperoleh dikatakan homogen jika p-value $>\alpha=0,05$. Pengujian hipotesis untuk menjawab hipotesis penelitian yang telah diajukan. Adapun maksud tersebut di atas, maka pengujian dilakukan dengan menggunakan uji-t (independent uji test) yaitu pengujian perbedaan rata-rata dua kelompok. tapi pengujian ini digunakan dengan bantuan komputer yaitu program SPSS.

\section{HASIL \& PEMBAHASAN}

Langkah awal yang dilakukan oleh peneliti adalah melakukan validitas instrument soal (pretest dan posttest), validitas yang digunakan adalah validitas isi dan validitas konstruk sebelum digunakan dan dilanjutkan dengan pemberian treatment penggunaan media puzzle untuk mengetahui pengaruh penggunaan media puzzle terhadap hasil belajar siswa pada mata pelajaran matematika.

\section{Deskripsi Data Pretest Kelas Eksperimen dan Kelas Kontrol Hasil Belajar Matematika.}

Berdasarkan hasil analisis yang dilakukan dapat dilihat bahwa standar deviasi nilai pretest kelas ekperimen dan kelas kontrol yang berarti bahwa pretest kelas eksperimen dan kelas kontrol lumayan beragam. Nilai ratarata, nilai tengah, dan modus berada pada kategori cukup Dengan penyebaran nilai terendah pada kelas eksperimen 35 dengan nilai tertingginya 70 dengan rentang 35 dan kelas kontrol nilai terendah 30 dari nilai tertinggi pada kelas 70 dengan rentang 40 .

Jika skor pretest hasil belajar kelas eksperimen dan kontrol tersebut dikelompokkan ke dalam 5 kategori, maka diperoleh tidak terdapat siswa yang berada pada kaegori baik dan sangat baik.

\section{Deskripsi Data Posttest Kelas Eksperimen dan Kelas Kontrol Hasil Belajar Matematika.}

Berdasarkan hasil analisis yang dilakuksn maka diperoleh bahwa standar deviasi nilai Posttest kelas ekperimen dan kelas kontrol yang berarti bahwa Posttest kelas eksperimen dan kelas kontrol lumayan beragam. Nilai rata-rata, nilai tengah, dan modus berada pada kategori cukup baik dengan penyebaran nilai terendah pada kelas eksperimen 45 dengan nilai tertingginya 95 dengan rentang 50 dan kelas kontrol nilai terendah 40 dari nilai tertinggi pada kelas 85 dengan rentang 45 .

Jika skor Posttest hasil belajar kelas eksperimen dan kontrol tersebut dikelompokkan ke dalam 5 kategori, maka 
terdapat siswa yang berada pada kategori baik dan sangat baik.

\section{Hasil Uji Normalitas}

Uji normalitas dilakukan untuk mengetahui apakah data yang diperoleh berdistribusi normal atau tidak normal. Syarat data dikatakan berdistribusi normal apabila signifikansi hasil uji lebih dari 0,05 . Berikut ini hasil uji normalitas data pretest dan posttest kelas eksperimen dan kelas kontrol.

Tabel 1. Hasil Uji Normalitas Data Pretest Dan Posttest Kelas Eksperimen Dan Kelas Kontrol

\begin{tabular}{lcc}
\multicolumn{1}{c}{ Data } & Sig. Kolmogorov-Smirnov & Keterangan \\
\hline Pretest Eksperimen & 0,200 & $0,200>0,05=$ normal \\
\hline Posttest Eksperimen & 0,200 & $0,150>0,05=$ normal \\
\hline Pretest Kontrol & 0,111 & $0,111>0,05=$ normal \\
\hline Postest Kontrol & 0,197 & $0,197>0,05=$ normal \\
\hline
\end{tabular}

\section{Hasil Uji Homogenitas}

Uji homogenitas dilakukan untuk mengetahui apakah data dari kedua sampel homogen. Serta untuk memenuhi syarat untuk melakukan uji parametrik, karena uji parametrik mengharuskan data yang akan diuji harus homogen. Data yang akan diuji homogenitasnya adalah hasil pretest kelas kontrol dan kelas eksperimen serta posttest kelas kontrol dan kelas eksperimen. Data dikatakan homogen apabila nilai signifikansinya lebih besar dari 0,05

Tabel 2. Hasil Uji Homogenitas

\begin{tabular}{lcc}
\multicolumn{1}{c}{ Data } & Signifikansi & Keterangan \\
\hline $\begin{array}{l}\text { Postest Kontrol dan } \\
\text { Eksperimen }\end{array}$ & 0,321 & $0,321>0,05=$ homogen \\
$\begin{array}{l}\text { Pretest Kontrol dan } \\
\text { Eksperimen }\end{array}$ & 0,347 & $0,347>0,05=$ homogen \\
\hline
\end{tabular}

\section{Hasil Uji Hipotesis}

Uji hipotesis dalam penelitian ini dilakukan utnuk mengetahui apakah ada perbedaan antara hasil pretest kelas kontrol dengan kelas eksperimen, Serta posttest kelas kontrolo dan kelas eksperimen. Jenis uji hipotesis yang digunakan adalah independent samples $T$ test. Independent samples $T$ test atau uji beda dua rata-rata digunakan untuk menguji rata-rata dari dua kelompok data yang independen atau dengan kata lain digunakan untuk menguji pengaruh variabel independen terhadap variabel dependen. Berikut ini adalah hasil uji hipotesis dengan menggunakan Independent samples $T$ test.

Tabel 3. Uji Independent Sample T Test Pretest Kontrol dan Pretest Eksperimen

\begin{tabular}{ccc}
\hline \multicolumn{1}{c}{ Data } & Asymp. Sig. (2-tailed) & Keterangan \\
\hline $\begin{array}{l}\text { Pretest Eksperimen } \\
\text { dan Kontrol }\end{array}$ & 0,838 & $0,838>0,05=$ normal \\
\hline
\end{tabular}

Tabel 4. Uji Independent Sample T Test Posttest Kontrol dan Posttest Eksperimen

\begin{tabular}{ccc}
\hline Data & Asymp. Sig. (2-tailed) & Keterangan \\
\hline $\begin{array}{l}\text { Posttest Eksperimen } \\
\text { dan Kontrol }\end{array}$ & 0,027 & $0,027<0,05=$ normal \\
\hline
\end{tabular}

Berdasarkan tabel tersebut dapat diketahui bahwa uji Hasil analisis statistik inferensial parametris uji independent samptes $t$ test diperoleh bahwa nilai signifikansi lebih kecil dari 0,05. Maka dapat disimpulkan bahwa:

Ho : Tidak ada pengaruh penggunaan media puzzle terhadap hasil belajar siswa pada 
mata pelajaran matematika Kelas III SD Inpres Taeng-Taeng Kabupaten Gowa = ditolak

$\mathrm{Ha}$ : Ada pengaruh penggunaan media puzzle terhadap hasil belajar siswa pada mata pelajaran matematika Kelas III SD Inpres Taeng-Taeng Kabupaten Gowa = diterima

\section{Pembahasan}

Penelitian ini bertujuan untuk mengetahui gambaran penggunaan media puzzle terhadap hasil belajar matematika pada siswa Kelas III SD Inpres Taeng-Taeng Kabupaten Gowa. Penelitian eksperimen dengan menggunakan desain TrueExperimental Design yaitu memberikan perlakuan penggunaan media puzzle pada kelas eksperimen dan pembelajaran konvensional pada kelas kontrol sebagai pembandingnya.

Sampel pada penelitian ini terdiri dari dua kelas yaitu kelas eksperimen dan kelas kontrol yang yang masing-masing jumlah siswanya sebanyak 28 orang. Kelas eksperimen merupakan kelas yang mendapatkan perlakuan berupa penggunaan media puzzle. Sedangkan kelas kontrol merupakan kelas yang mendapatkan perlakuan tanpa menggunakan media puzzle.

\section{Gambaran Media media puzzle terhadap Hasil belajar Matematika \\ Selama proses pembelajaran} berlangsung, siswa kelas eksperimen yang menggunakan media puzzle terlihat lebih tertarik dalam memperhatikan materi yang disampaikan oleh peneliti. Selain itu, siswa lebih cepat tanggap dalam pemahaman materi serta lebih aktif dalam pembelajaran dibandingkan dengan kelas kontrol. Media dakon matematika dapat dikatakan lebih efektif dalam menciptakan suasana belajar yang disukai oleh siswa sehingga siswa lebih senang belajar dan mendapatkan hasil yang optimal.

Sebelum memberikan perlakuan pada kelas eksperimen terlebih dahulu diberikan pretest untuk memperoleh data awal pada kelas eksperimen. Setelah pemberian pretest selanjutnya diberikan perlakuan dengan menggunakan media dakon matematika. Setelah pemberian perlakuan selanjutnya yang dilakukan yaitu memberikan posttest untuk mengetahui hasil belajar siswa setelah diberikan perlakuan. Berdasarkan analisis deskriptif yang dilakukan diketahui bahwa hasil pretest dan posttest hasil belajar kelas eksperimen berada pada kategori cukup baik dengan nilai rata-rata pada pretest yaitu 50,36 dan posttest yaitu 72,50.

Selain pada kelas eksperimen, pretest juga diberikan kepada kelas kontrol untuk mengetahui data awal pada kelas konrol. Setelah pretest kemudian kelas kontrol mendapatkan perlakuan dengan tidak menggunakan media puzzle. Posttest diberikan untuk mengetahui hasil belajar kelas kontrol setelah perlakuan tanpa menggunakan media puzzle. Hasil analisis deskriptif yang telah diperoleh yaitu hasil pretest dan posttest pada kelas kontrol berada pada kategori cukup baik dengan nilai rata-rata pada pretest yaitu 49,82 dan posttest yaitu 64,64.

Berdasarkan hasil analisis data deskriptif tersebut bahwa hasil belajar pada kelas eksperimen dan kelas kontrol berada pada kategori cukup baik setelah pemberian perlakuan.

Penggunaan media puzzle memberikan dampak yang positif bagi pembelajaran, contohnya dalam menambah minat belajar siswa sehingga siswa menjadi lebih aktif dalam pembelajaran. Pembelajaran juga menjadi mudah lebih menyenangkan bagi siswa karena media puzzle memudahkan siswa dalam memahami pelajaran matematika khususnya pada materi pecahan. Pelaksanaan pembelajaran dengan menggunakan media puzzle matematika berlangsung secara efektif dikarenakan presentase kategori kelas eksperimen mengalami peningkatan. Sehingga hal ini dapat mempengaruhi hasil belajar siswa pada mata pelajaran matematika siswa Kelas III SD Inpres Taeng-Taeng Kabupaten Gowa.

\section{Pengaruh Media Dakon Terhadap Hasil Belajar}

Berdasarkan hasil uji independen samples $t$ test yang telah dilakukan terhadap kelas eksperimen dan kontrol, diketahui bahwa terdapat perbedaan hasil belajar siswa. Perbedaan yang pertama yaitu perbedaan sebelum dan sesudah diberikan perlakuan berupa penggunaan media puzzle pada kelas eksperimen dan tidak pada kelas kontrol. Perbedaan selanjutnya yaitu perbedaan hasil belajar antara kelas yang melaksanakan pembelajaran menggunakan media puzzle dan hasil belajar kelas yang tidak menggunakan media dakon matematika.

Jika dilihat dari perbedaan sebelum dan sesudah pemberian perlakuan pembelajaran dengan media puzzle, diketahui bahwa terdapat peningkatan rata-rata hasil belajar pada kelas eksperimen yaitu 50,36 
menjadi 72,50. Hal tersebut menujukkan bahwa terdapat perbedaan hasil belajar sebelum dan sesudah diberikan perlakuan. Jika ditinjaudari rata-rata hasil pretest dan posttest kelas kontrol diketahui bahwa mengalami peningkatan tetapi tidak sebesar pada kelas ekspeimen.

Selanjutnya ditinjau dari hasil belajar kelas eksperimen yang mendapatkan perlakuan penggunaan media puzzle dan kelas kontrol. Pada hasil pengujian yang telah dilakukan dimana hasil pretest kelas eksperimen dan kelas kontrol diketahui bahwa tidak memiliki perbedaan yang signifikan dengan nilai signifikansi yang lebih dari 0,05 yaitu sebesar 0,838 . Sedangkan nilai rata-rata hasil posttest kelas eksperimen dan kelas kontrol dengan nilai signifikansi yang berada dibawah lebih kecil dari 0,05 yaitu sebesar 0,027 diketahui bahwa terdapa perbedaan yang signifikan. Hasil penelitian tersebut menunjuukan bahwa terdapat perbedaan yang signifikan dari kelas yang mendapatkan perlakuan penggunaan media puzzle dengan yang tidak menggunakan media puzzle. Sejalan dengan hasil penelitian. Berdasarkan hasil penelitian bahwa penggunaan media puzzle dapat mempengaruhi hasil belajar siswa pada mata pelajaran matematik, selain itu pembelajaran menjadi lebih menyenangkan dan menjadikan siswa lebih aktif dalam proses pembelajaran dengan penggunaan media puzzle tersebut. Maka simpulan penelitian ini yaitu terdapat pengaruh penggunaan media puzzle terhadap hasil belajar siswa pada mata pelajaran matematika Kelas III SD Inpres Taeng-Taeng Kabupaten Gowa.

\section{KESIMPULAN \& SARAN}

Hasil penelitian menunjukkan bahwa: Penggunaan media Puzzle pada mata pelajaran matematika di Taeng-Taeng Kabupaten Gowa memberikan pengaruh positif terhadap peningkatan hasil belajar siswa yang meningkat sehingga memberikan pengaruh yang signifikan.

\section{DAFTAR PUSTAKA}

Ahmad, Abdul., 2007. Media Pembelajaran. Makassar: Badan Penerbit UNM

Alfiatun N, dkk. 2013. "Efektivitas Kombinasi Kooperatif Time Token dengan Picture Puzzle Materi Sistem Peredaran Darah". Unnes Journal of Biology Education, (Online), Vol. 02, No. 02, (http://journal.unnes.ac.id, diunduh 02 Juni 2017).

Azhar Arsyad. 2014. Media Pembelajaran. Jakarta: Raja Grafindo Persada.

Ayu, Shinta., 2014. Segudang Game Edukatif Mengajar. Yogyakarta: Diva Press

Hamzah, Ali \& Muhlisrarini., 2014. Perencanaan dan Strategi Pembelajaran

Matematika. Jakarta: PT Rajagrafindo Persada

Heruman., 2007. Model Pembelajaran Matematika Di Sekolah Dasar. Bandung: PT Remaja Rosdakarya

Hiedayat, S. W. dan Sulistyowati. 2010. Pengembangan Komputer Pembelajaran (CAI) tentang Gerak Lurus Berubah Beraturan pada Mata Pelajaran Fisika bagi Siswa Kelas VII SMP Negeri 2 Surabaya. Jurnal Teknologi Pendidikan Universitas Negeri Surabaya 10 (1): 8699.

Kristanto, A. 2010. Pengembangan Media Komputer Pembelajaran Multimedia Mata Pelajaran Fisika Pokok Bahasan Sistem Tata Surya bagi Siswa Kelas 2 Semester I di SMAN 22 Surabaya. Jurnal Teknologi Pendidikan Universitas Negeri Surabaya 10 (2): 1225.

Latif, Mukhtar. Dkk., 2014. Orientasi Baru Pendidikan Anak Usia Dini Teori dan Aplikasi. Telanaipura: Kencana

Prima, Aurelia., 2016. Aneka Permainan Kreatif dan Edukatif untuk Anak. Yogyakarta: Diva Press

Riyanto, Yatim., 2010. Paradigma Baru Pembelajaran. Surabaya: Kencana

Rusman. 2015. Pembelajaran Tematik Terpadu Teori Praktik dan Penilaian. Bandung: Rajawali Pers

Sadiman. Arif. 2012. Media Pendidikan (Pengertian, Pengembangan, dan Pemanfaatannya). Jakarta: PT RajaGrafindo Persada

Siatan, Diah., 2014. Pengaruh Pembelajaran Matematika dengan Menggunakan Media Puzzle dengan Materi Bangun Ruang Terhadap Hasil Belajar Siswa di SD. Skripsi. Jakarta: Program Sarjana UIN Syarif Hidayatullah

Sugiyono., 2015. Metode Penelitian Pendidikan. Bandung: Alfabeta

Suprijono, Agus., 2015. Cooperative Learning Teori \& Aplikasi Pakem. Surabaya: Pustaka Pelajar 
Suryabrata, Sumadi., 2012. Psikologi Pendidikan. Yogyakarta: RajaGrafindo Persada

Susanto, Ahmad., 2014. Teori Pembelajaran di $S D$. Jakarta: Kencana

Tilong, Adi D., 2016. 49 Aktivitas Pendokrak Kinerja Otak Kanan \& Kiri Anak. Yogyakarta: Laksana 